\title{
Cloning and recombinant expression of a cellulase from the cellulolytic strain Streptomyces sp. G12 isolated from compost
}

Antonella Amore ${ }^{1}$, Olimpia Pepe ${ }^{2}$, Valeria Ventorino ${ }^{2}$, Leila Birolo ${ }^{1,3}$, Chiara Giangrande ${ }^{1}$ and Vincenza Faraco ${ }^{1,3^{*}}$

\begin{abstract}
Background: The use of lignocellulosic materials for second generation ethanol production would give several advantages such as minimizing the conflict between land use for food and fuel production, providing less expensive raw materials than conventional agricultural feedstock, allowing lower greenhouse gas emissions than those of first generation ethanol. However, cellulosic biofuels are not produced at a competitive level yet, mainly because of the high production costs of the cellulolytic enzymes. Therefore, this study was aimed at discovering new cellulolytic microorganisms and enzymes.
\end{abstract}

Results: Different bacteria isolated from raw composting materials obtained from vegetable processing industry wastes were screened for their cellulolytic activity on solid medium containing carboxymethylcellulose. Four strains belonging to the actinomycetes group were selected on the basis of their phenotypic traits and cellulolytic activity on solid medium containing carboxymethylcellulose. The strain showing the highest cellulolytic activity was identified by $16 \mathrm{~S}$ rRNA sequencing as belonging to Streptomyces genus and it was designated as Streptomyces sp. strain G12. Investigating the enzymes responsible for cellulase activity produced by Streptomyces G12 by proteomic analyses, two endoglucanases were identified. Gene coding for one of these enzymes, named CelStrep, was cloned and sequenced. Molecular analysis showed that the celstrep gene has an open reading frame encoding a protein of 379 amino acid residues, including a signal peptide of 37 amino acid residues. Comparison of deduced aminoacidic sequence to the other cellulases indicated that the enzyme CelStrep can be classified as a family 12 glycoside hydrolase. Heterologous recombinant expression of CelStrep was carried out in Escherichia coli, and the active recombinant enzyme was purified from culture supernatant and characterized. It catalyzes the hydrolysis of carboxymethylcellulose following a Michaelis-Menten kinetics with a $K_{M}$ of $9.13 \mathrm{mg} / \mathrm{ml}$ and a $v_{\max }$ of $3469 \mu \mathrm{M} \mathrm{min}^{-1}$. The enzyme exhibits a half life of around $24 \mathrm{~h}$ and $96 \mathrm{~h}$ at $60^{\circ} \mathrm{C}$ and $50^{\circ} \mathrm{C}$, respectively and shows a retention of around $80 \%$ of activity after $96 \mathrm{~h}$ at $40^{\circ} \mathrm{C}$.

Conclusions: In this manuscript, we describe the isolation of a new cellulolytic strain, Streptomyces sp. G12, from industrial waste based compost, the identification of the enzymes putatively responsible for its cellulolytic activity, the cloning and the recombinant expression of the gene coding for the Streptomyces sp. G12 cellulase CelStrep, that was characterized showing to exhibit a relevant thermoresistance increasing its potential for cellulose conversion.

Keywords: Streptomyces, Cellulases, Recombinant expression

\footnotetext{
* Correspondence: vfaraco@unina.it

'Department of Chemical Sciences, University of Naples "Federico II",

Complesso Universitario Monte S. Angelo, via Cintia, 4, 80126, Naples, Italy

${ }^{3}$ School of Biotechnological Sciences, University of Naples "Federico II",

Portici, Napoli, Italy

Full list of author information is available at the end of the article
}

\section{Biomed Central}

(c) 2012 Amore et al.; licensee BioMed Central Ltd. This is an Open Access article distributed under the terms of the Creative Commons Attribution License (http://creativecommons.org/licenses/by/2.0), which permits unrestricted use, distribution, and reproduction in any medium, provided the original work is properly cited. 


\section{Background}

Demand for energy has more than doubled in the last 30 years in the Mediterranean where an underexploitation of biomass for biofuel production takes place, biomass accounting for just $21 \%$ of the total renewable capacity. Adopting lignocellulosic residues as raw materials for effective large-scale production of bioethanol fuel in the Mediterranean is an urgent requirement if the region's growing energy demands are to be met and the climate change effects there alleviated [1]. Lignocellulosic biomass is an attractive material for production of a wide range of high added value products, such as fuel ethanol. Lignocellulose is the most abundant renewable resource on Earth, and it constitutes a large component of the wastes originating from municipal, agricultural, forestry and some industrial sources. The use of lignocellulosic materials would minimize the conflict between land use for food and feed production and energy and bioproducts feedstock production. This raw material is less expensive than conventional agricultural feedstock and can be produced with lower input of fertilizers, pesticides and energy [2].

However, cellulosic biofuels are not produced at a competitive level yet, due to the high cost of processing with the currently available technologies [3].

Conversion of cellulose into fermentable sugars for ethanol production is currently performed by enzymatic hydrolysis carried out by cellulases, produced by a wide variety of microorganisms, depolymerizing such a polymer and playing a major role in the recycling of biomass. Wild type and mutant strains of Trichoderma spp., have long been considered to be the most powerful producers of cellulases [4]. The production costs of these enzymes are very high and a huge amount of hydrolytic enzymes is required for hydrolysis on industrial scale.

Bacteria, showing higher growth rate than fungi have good potential to be used in cellulase production. Among bacteria, the actinomycetes Thermomonospora fusca [5-8], Streptomyces thermodiastaticus [5], Thermomonospora curvata [9-13], Streptomyces viridosporus and S. setonii [14] as well as other strains of Streptomyces sp. [15,16] and other actinomycetes [17] were reported as producers of cellulolytic activity.

This study was aimed at isolating a new cellulolytic bacterium and characterizing the enzymes responsible for its cellulolytic capabilities in order to catch better biocatalysts for second generation ethanol production. Identification of the enzymes putatively responsible for the cellulolytic activity of the strain Streptomyces sp. G12, the most active cellulase producer among the cellulolytic actinomycetes isolated from compost, is reported. Moreover, cloning and sequencing of the gene encoding one of the identified cellulases and its heterologous recombinant expression in Escherichia coli are described along with characterization of the recombinant enzyme.

\section{Methods}

\section{Cellulolytic bacteria isolation}

Cellulolytic microorganisms were isolated from mature compost obtained from agro-industrial wastes consisting of pomace with kernel (65\%), liquid sewage sludge (22\%) from industrial processing of vegetable (potatoes and carrotoes) and borland molasses (13\%). Representative samples of $1 \mathrm{Kg}$ were taken from the external (right and left side of the pile, about $5-10 \mathrm{~cm}$ of depth) and internal central part (at about $40 \mathrm{~cm}$ of depth) of biomass. Microbial isolates were obtained in solid media following the method described by Hankin and Anagnostic [18] with some modifications. Initial compost suspensions were prepared by the addition of $20 \mathrm{~g}(\mathrm{w} / \mathrm{v})$ of compost samples to $180 \mathrm{ml}$ of quarter strength Ringer's solution (Oxoid, Ltd., Oxford, UK) in $250 \mathrm{ml}$ Erlenmeyer flasks. After shaking, suitable dilutions were made in the same solution and were used to inoculate solid media of growth composed by $5 \mathrm{~g} \mathrm{~L}^{-1}$ carboxymethylcellulose (CMC) (Sigma-Aldrich Chemie GmbH, Steinheim, Germany), $1 \mathrm{~g} \mathrm{~L}^{-1}\left(\mathrm{NH}_{4}\right) \mathrm{NO}_{3}, 1 \mathrm{~g} \mathrm{~L}^{-1}$ yeast extract, $50 \mathrm{ml} \mathrm{L}^{-1}$ standard salt solution, $1 \mathrm{ml} \mathrm{L}^{-1}$ trace elements solution, $0.02 \%$ Remazol Brilliant Blue R [19], $10 \mathrm{~g} \mathrm{~L}^{-1}$ bacteriological agar, at $\mathrm{pH}$ 7.0. After incubation at $28^{\circ} \mathrm{C}$ for 7 days, the plates were flooded with a Remazol Brilliant Blue $\mathrm{R}$ solution to put better in evidence the presence of clear haloes around the cellulolytic colonies. Single colonies were picked and checked for purity by repetitive streaking on $\mathrm{CMC}$ solid medium. All isolates were kept at $4{ }^{\circ} \mathrm{C}$ on solid medium until analyses.

\section{Screening on solid and liquid media}

Solid media composition, used for the screening of microbial isolates, was the same described above without Remazol Brilliant Blue R. The plates were incubated at $28^{\circ} \mathrm{C}$ for 4 days. Afterwards, the strains were assayed for their ability to degrade CMC by incubation with $0.1 \%$ Congo red solution for 30 minutes followed by washing with $5 \mathrm{M} \mathrm{NaCl}$ [20]. All the strains with a clear halo around the colonies were chosen as positive. A comparison of the cellulase production was then carried out by agar spot method. After adjusting the turbidity of tested bacterial suspensions by comparison with McFarland Turbidity Standard at the value 0.5 (corresponding to about $1.5 * 10^{8} \mathrm{CFUmL}^{-1}$ ), in $25 \mathrm{~mL}$ of Ringer solution (Sigma-Aldrich), cells were spotted on agar medium in triplicate. Spots were incubated at $28^{\circ} \mathrm{C}$ for 4 days, stained with $0.1 \%$ Congo red and activity halos dimensions were measured from the border of the colony to the outer edge of the halo. Experiments were performed in duplicate. 
The liquid medium adopted for analysis of cellulase production levels contained 1\% CMC, 0.25\% $\left(\mathrm{NH}_{4}\right)_{2} \mathrm{SO}_{4}$, $0.05 \%$ yeast extract, $0.27 \% \mathrm{KH}_{2} \mathrm{PO}_{4}, 0.53 \% \mathrm{Na}_{2} \mathrm{HPO}_{4}$, $0.02 \% \mathrm{NaCl}, 0.02 \% \mathrm{MgSO}_{4}-7 \mathrm{H}_{2} \mathrm{O}, 0.005 \% \mathrm{CaCl}_{2}$ [5]. As far as Streptomyces strain G12 is concerned, other carbon sources were tested replacing $\mathrm{CMC}$ with an equivalent carbon amount of glucose, cellobiose, xylose or xylan (AppliChem, Germany), or using a combination of $0.6 \% \mathrm{CMC}$ and $0.4 \%$ glucose or cellobiose. For this strain, submerged fermentation was also carried out using wheat straw $(2 \% \mathrm{w} / \mathrm{v})$ as carbon source and testing different concentrations of yeast extract (0.05\%, $0.1 \%$, $0.7 \%)$. The straw was reduced in small piece and sieved to have different dimension particles $(<0.8 \mathrm{~mm}, 0.8$ $2 \mathrm{~mm},>2 \mathrm{~mm})$, moisturized with water $(1: 1 \mathrm{w} / \mathrm{v})$ and autoclaved for $1 \mathrm{~h}$ at $110^{\circ} \mathrm{C}$.

\section{Phenotypic characterization of microbial isolates}

Morphological analysis of colony of each bacterial strain was carried out observing shape (regular/irregular/rhizoid/ punctiform/filamentous), edge (entire/undulate), surface (dry/viscid/powdery), elevation (flat/raised) and colour of colony.

The presence of the enzyme cytochrome oxidase was detected with commercial Oxidase strips (Oxoid Ltd, England).

Gram-positive and gram-negative microorganisms were distinguished by mean of $\mathrm{KOH}$ test as described by Halebian et al. [21].

The cellular morphology was studied with the optic microscope Eclipse E200 (Nikon).

\section{Inoculum preparation and fermentation process}

The bacterial strains were pre-inoculated dissolving a single colony in $10 \mathrm{~mL}$ of liquid medium having the composition described in the second paragraph of Methods section "Screening on solid and liquid media" and incubated over night at $28^{\circ} \mathrm{C}$. Fermentation was carried out in $250 \mathrm{ml}$ plugged Erlenmeyer flasks, each containing $50 \mathrm{~mL}$ of medium and inoculated with volumes of pre-inoculum corresponding to 0.8 O.D. After pre-inocula homogenization by ULTRA-TURRAX ${ }^{\circledR}$, The inocula were incubated at $28^{\circ}$ $\mathrm{C}$ on rotary shaker at $225 \mathrm{rpm}$ for fifteen days. When indicated, a higher temperature in the range $28-47^{\circ} \mathrm{C}$ was adopted. From time to time, samples of liquid cultures were withdrawn and used for measurement of optical density (O.D.600nm) and extracellular cellulase activity. The results of these determinations reported in the figures and tables correspond to mean values of three independent experiments performed in three replicates.

\section{Intracellular protein extraction}

Intracellular crude protein extract of Streptomyces G12 was obtained by using a French press (Constant System,
UK). Pellets obtained after 6 days of growth in liquid culture were resuspended in sodium phosphate $50 \mathrm{mM}$ $\mathrm{pH} 6.5$, before applying a pressure of around $2.5 \mathrm{kbar}$.

\section{CMCase ctivity spot assay on solid medium}

A preliminary analysis of levels of cellulase production in liquid medium was performed spotting 50 microliter of culture supernatants from different growth times $(4 \mathrm{~h}$, 5 h, 6 h, 7 h, 8 h, 9 h, 14 h, 15 h, 17 h, 20 h and 24 h) on solid CMC medium. After $1 \mathrm{~h}$ incubation at $50^{\circ} \mathrm{C}$, the $\mathrm{CMC}$ plates were flooded by $0.1 \%$ Congo red staining, as described in the second paragraph of Methods section "Screening on solid and liquid media".

\section{Azo-CMC assay}

endo-1,4-ß-Glucanase activity produced in liquid or submerged culture was assayed by using Azo-CMC (Megazyme, Ireland) as substrate, following supplier instructions and determined by referring to a standard curve.

\section{Azo-avicelase assay}

Avicelase activity was measured by using Azo-Avicel (Megazyme, Ireland) as substrate, following supplier instructions.

\section{S rRNA partial sequence}

Total genomic DNA of selected strains was extracted and purified using InstaGene ${ }^{\mathrm{TM}}$ Matrix (Bio-Rad Laboratories, Hercules, CA) according to the supplier's recommendations. Two synthetic oligonucleotide primers at the 5' and 3' end of the 16S rDNA, described by Kumar et al. [22] 9F GAGTTTGATCCTGGCTCAG and 1541R AAGGA GGTGATCCAACC were used to amplify the 16S rRNA gene. PCR was performed as previously reported [23]. The PCR amplification fragment was purified by agarose $(1.5 \%$ wt/vol) gel electrophoresis using a QIAquick gel extraction kit (Qiagen S.p.A., Milan, Italy) and sequenced. The DNA sequencing was ordered at Primm srl (Milan, Italy). The sequences were analysed by MacDNasis Pro v3.0.7 (Hitachi Software Engineering Europe S. A., Olivet Cedex, F) and compared to the GenBank nucleotide data library using the Blast software at the National Centre of Biotechnology Information website (http://www.ncbi.nlm.nih.gov), in order to determine their closest phylogenetic relatives.

The partial 16S rDNA sequence of the isolate G12 has been submitted to EMBL, and the accession number is HE585989.

\section{Determination of protein concentration}

Protein concentration of crude enzyme preparation was determined by Bradford method using Biorad reactive (München, Germany) following the procedure suggested by the supplier. Bovin serum albumin (BSA) was used to set up the standard curve. 


\section{Enzyme identification Protein fractionation}

Secreted proteins produced by Streptomyces sp. G12 were precipitated from the cultures corresponding at the maximum cellulase production by the addition of ammonium sulphate up to $80 \%$ saturation, after having removed cells by centrifugation. Precipitated proteins were recovered by centrifugation at $7500 \mathrm{rpm}$ for $45 \mathrm{~min}$ utes at $4^{\circ} \mathrm{C}$ and brought in $50 \mathrm{mM} \mathrm{Na}_{2} \mathrm{HPO}_{4} \mathrm{pH} 6.5$, by dialysis through ultrafiltration devices with a cut-off of $10 \mathrm{kDa}$ (Millipore S.p.A., Vimodrone Italy).

\section{Zymogram analyses}

Semi-denaturing gel electrophoresis was carried out loading non-denatured and not-reduced samples on a SDS polyacrylamide gel, performed as described by Laemmli [24]. Proteins showing cellulolytic activity were visualized following a modified version of the assay reported by Béguin [25]. After electrophoresis, the gel was soaked in the same buffer used for dissolving proteins and gently shaken to remove SDS and rinature the proteins in the gel. The gel was then laid on the top of a thin sheet of $1.5 \%$ agar containing $1 \% \mathrm{CMC}$. After $1 \mathrm{~h}$ incubation at $40^{\circ} \mathrm{C}$, zones of $\mathrm{CMC}$ hydrolysis were revealed by staining the agar replica with $0.1 \%$ of Congo red.

\section{Protein identification by mass spectrometry}

Slices of interest from the semi-denaturing PAGE were cut and in situ digested after extensive destaining with $0.1 \mathrm{M} \mathrm{NH}_{4} \mathrm{HCO}_{3} \mathrm{pH} 7.5$ and acetonitrile, reduction of disulphide bonds for 45 minutes in $100 \mu \mathrm{l}$ of $10 \mathrm{mM}$ dithiothreitol, $0.1 \mathrm{M} \mathrm{NH}_{4} \mathrm{HCO}_{3}$, pH 7.5 and carboxyamidomethylation of thiols for 30 minutes in the dark by addition of $100 \mu \mathrm{l}$ of $55 \mathrm{mM}$ iodoacetamide dissolved in the same buffer. Enzymatic digestion was performed by adding to each slice $100 \mathrm{ng}$ of proteomic-grade trypsin in $10 \mu \mathrm{l}$ of $10 \mathrm{mM} \mathrm{NH}_{4} \mathrm{HCO}_{3} \mathrm{pH} 7.5$ for 2 hours at $4^{\circ} \mathrm{C}$. The buffer solution was then removed and $50 \mu \mathrm{l}$ of $10 \mathrm{mM} \mathrm{NH}_{4} \mathrm{HCO}_{3} \mathrm{pH} 7.5$ were added and incubated for 18 hours at $37^{\circ} \mathrm{C}$. Peptides were extracted with $20 \mu \mathrm{l}$ of $10 \mathrm{mM} \mathrm{NH} \mathrm{NHCO}_{3}, 1 \%$ formic acid, $50 \%$ acetonitrile at room temperature.

Peptide mixtures were filtered on $0.22 \mu \mathrm{m}$ PVDF membrane (Millipore) and analysed by LC-MSMS on a 6520 Accurate-Mass Q-TOF LC/MS System (Agilent Technologies, Palo Alto, CA) equipped with a 1200 HPLC system and a chip cube (Agilent Technologies). After loading, the peptide mixture is concentrated and washed in $40 \mathrm{~nL}$ enrichment column (Agilent Technologies chip), with $0.1 \%$ formic acid in $2 \%$ acetonitrile as the eluent. The sample is then fractionated on a C18 reverse-phase capillary column (Agilent Technologies chip) at a flow rate of $400 \mathrm{nl} / \mathrm{min}$, with a linear gradient of eluent B (0.1\% formic acid in $95 \%$ acetonitrile) in A
( $0.1 \%$ formic acid in $2 \%$ acetonitrile) from 7 to $80 \%$ in 50 min. Peptide analysis is performed using datadependent acquisition of one MS scan (mass range from 300 to $1800 \mathrm{~m} / \mathrm{z}$ ) followed by MS/MS scans of the five most abundant ions in each MS scan. MS/MS spectra were measured automatically when the MS signal is over the threshold of 50000 counts. Double and triple charged ions were preferably isolated and fragmented over single charged ions. Raw data from nanoLC-MS/ MS analyses transformed in mz.data format and used to query nonredundant protein databases with a licensed version of MASCOT 2.1 (Matrix Science, Boston, USA). Additional search parameters were a peptide mass tolerance set at $10 \mathrm{ppm}$ and a fragment mass tolerance of $0.6 \mathrm{Da}$, up to 3 allowed missed cleavages, carbamidomethylation of cysteines as fixed modification, oxidation of methionine, and cyclization of N-term Q to pyro-Glu as variable modifications. Only doubly and triply charge ions were considered. Ions score is $-10 \log (\mathrm{P})$, where $\mathrm{P}$ is the probability that the observed match is a random event. The threshold above which the individual ions score indicates identity or extensive homology $(\mathrm{p}<0.05)$ can vary from search to search. In our searches, on average, individual ion scores $>25$ indicated identity or extensive homology $(\mathrm{p}<0.05)$. Protein scores are derived from ions scores as a nonprobabilistic basis for ranking protein hits (http://www.matrixscience.com/help/interpretation_help.html). Trypsin, dithiothreitol, iodoacetamide and $\mathrm{NH}_{4} \mathrm{HCO}_{3}$ were purchased from Sigma. Trifluoroacetic acid (TFA)-HPLC grade was from Carlo Erba (Milan, Italy). All other reagents and solvents were of the highest purity available from Baker.

\section{Gene isolation and sequencing}

Chromosomal high-molecular weight DNA from Streptomyces sp. G12 was prepared as described by Raeder and Broda [26]. To synthesize gene coding for the enzyme CelStrep from Streptomyces sp. G12, Polymerase Chain Reaction (PCR) experiments were performed using Streptomyces sp. G12 genomic DNA as template and degenerate and specific oligonucleotide primers reported in Table 1: central region was amplified with the oligonucleotides $1 \mathrm{FW} / 1 \mathrm{REV}$, the 5 ' terminal region

\begin{tabular}{|c|c|c|}
\hline Primer & Nucleotide sequence & Annealing temperature $\left({ }^{\circ} \mathrm{C}\right)$ \\
\hline $1 \mathrm{FW}$ & GCCACCGACTCSGGCTTC & 62 \\
\hline 1 REV & CKGTTGAACCAGATCAT & $48-50$ \\
\hline $2 \mathrm{FW}$ & ATGCCSCGSCTSCGSCACCAC & 74 \\
\hline 2 REV & CGCCCCCACGGCGAACC & 62 \\
\hline $3 \mathrm{FW}$ & CGCCTCGTACGACATCTGG & 62 \\
\hline 3 REV & SACAGTSGAGCASGCSGTSCC & 74 \\
\hline
\end{tabular}


with the oligonucleotides $2 \mathrm{FW} / 2 \mathrm{REV}$, the 3' terminal region with the oligonucleotides $3 \mathrm{FW} / 3 \mathrm{REV}$ and their sequencing by dideoxy chain termination method was performed by PRIMM Sequencing Service (Naples, Italy), using universal and specific oligonucleotide primers.

\section{Analysis of gene and protein sequences}

Sequence of gene coding for the enzyme CelStrep from Streptomyces sp. G12, named celstrep, was deposited with the EMBL Data Library under accession number HE862416. Alignments of DNA and of deduced amino acid sequences were generated using ClustalW2 (http:// www.ebi.ac.uk/Tools/clustalw2/index.html). Signal peptide prediction was achieved using SignalP V4.0 (http://www. cbs.dtu.dk/services/SignalP/). Potential $\mathrm{N}$-glycosylation sites (Asn-XXX-Ser/Thr) were computed on the NetNGlyc 1.0 server (http://www.cbs.dtu.dk/services/NetNGlyc/).

\section{Heterologous recombinant expression}

Gene celstrep was cloned into the expression vector pET28a (Novagen, Inc.) by NdeI and HindIII restriction sites to generate celstrep-pET28a, and it was expressed in E. coli strain BL21 CodonPlus (DE3) RP (Novargen Ltd).

Cells were cultured with a rotary shaker at $37^{\circ} \mathrm{C}$ until $1 \mathrm{OD}_{600}$ and protein expression was induced with $1 \mathrm{mM}$ isopropyl- $\beta$-D-thiogalactopyranoside (IPTG) for $6 \mathrm{~h}$ at $37^{\circ} \mathrm{C}$.

After centrifugation, supernatant was assayed for AzoCMCase activity and the cells were used to obtain intracellular crude protein extract by using a French press (Constant System, UK). Pellets of liquid cultures were resuspended in Na phosphate $50 \mathrm{mM}$ pH6.5, before applying a pressure of around 2.5 kbar. After centrifugation, the soluble fraction was also adopted to assay cellulase activity.

\section{Recombinant enzyme purification}

Proteins present in the culture supernatant of E. coli expressing celstrep at maximum production time were precipitated with ammonium sulphate up to $80 \%$ saturation and brought in $20 \mathrm{mM}$ Tris- $\mathrm{HCl} \mathrm{pH} \mathrm{7.} \mathrm{The} \mathrm{pro-}$ teins were then loaded on HiTrap Phenyl FF high sub (GE Healthcare, Uppsala, Sweden) equilibrated in buffer A (0.02 M Tris-HCl, 1.2 M (NH4)2SO4, pH 7.5), and the proteins were eluted isocratically with buffer $\mathrm{B}$ $(0.02 \mathrm{M}$ Tris- $\mathrm{HCl} \mathrm{pH}$ 7.5). Fractions containing activity were combined and concentrated on an Amicon PM-10 membrane and analyzed by SDS-PAGE.

\section{Recombinant enzyme characterization}

\section{Optimum temperature and temperature resistance}

To determine the optimum temperature of the purified recombinant enzyme, the substrate of the activity assay (Azo-CMC) was dissolved in $100 \mathrm{mM}$ sodium acetate buffer at $\mathrm{pH} 4.8$ and the incubation (10 min) was performed at $30^{\circ} \mathrm{C}, 40^{\circ} \mathrm{C}, 50^{\circ} \mathrm{C}, 60^{\circ} \mathrm{C}, 70^{\circ} \mathrm{C}$ and $80^{\circ} \mathrm{C}$. The thermo-resistance of CelStrep was studied by incubating the purified enzyme preparation in $100 \mathrm{mM}$ sodium acetate buffer $\mathrm{pH} 4.8$, at $40^{\circ} \mathrm{C}, 50^{\circ} \mathrm{C}, 60^{\circ} \mathrm{C}, 70^{\circ} \mathrm{C}$ and $80^{\circ} \mathrm{C}$. The samples withdrawn were assayed for residual AzoCMCase activity.

The results of these experiments reported in the manuscript correspond to mean values of three independent experiments performed in three replicates.

\section{Determination of $v_{\max }$ and $K M$}

For the experiments of enzyme kinetics characterization, cellulase activity was assayed in the total reaction mixture of $1 \mathrm{ml}$ containing $0.5 \mathrm{ml}$ of suitably diluted enzyme and $0.5 \mathrm{ml}$ of $2 \%(\mathrm{w} / \mathrm{v}) \mathrm{CMC}$ solution in $50 \mathrm{mM}$ citrate buffer at $\mathrm{pH} 4.8$. This mixture was incubated at $40^{\circ} \mathrm{C}$ for $30 \mathrm{~min}$. The release of reducing sugars was determined by the 3,5-dinitrosalicylic acid (DNS) method [27]. One unit of cellulase activity was defined as the amount of enzyme that liberated $1 \mu \mathrm{mol}$ reducing sugar per minute from substrate.

The values of Michaelis-Menten constants $\left(K_{M}\right.$ and $\mathrm{v}_{\max }$ ) of purified recombinant cellulase were identified by linear regression plots of Lineweaver and Burk. The enzyme was incubated at $50^{\circ} \mathrm{C}$ with the substrates of different concentrations of $\mathrm{CMC}$ ranging from 0.5 to $50 \mathrm{mg} / \mathrm{ml}$ in $50 \mathrm{mM}$ citrate buffer at $\mathrm{pH} 4.8$.

The results of these experiments reported in the manuscript correspond to mean values of three independent experiments performed in three replicates.

\section{Results and discussion}

Screening and selection of cellulolytic microorganisms Screening and phenotypic characterization of cellulolytic microorganisms

Ninety microorganisms isolated from mature compost obtained from agro-industrial wastes were screened for their cellulolytic activity on CMC solid medium, by Congo red staining. From this preliminary selection, 4 cellulolytic bacteria with a clear halo diameter from 6 to $17 \mathrm{~mm}$ around the colonies (data not shown) were selected.

The four microorganisms selected on solid medium were characterized from a phenotypic point of view by analysis of colony and cell morphology, gram reaction, and the oxidase activities. On the basis of these results, the analyzed microorganisms were grouped in two phenotypes. All the strains showed myceliar morphology, 
Table 2 Phenotype of the selected actinomycetes strains

\begin{tabular}{lcc}
\hline PHENOTYPE & $\mathbf{F}$ & $\mathbf{G}$ \\
\hline Strain & $\mathbf{1 4}_{\mathbf{9}, \mathbf{1 4}_{\mathbf{1 3}}}$ & $\mathbf{1 4}, \mathbf{G 1 2}$ \\
\hline Colony morphology & Grey regular mycelium with white margins & White-grey regular mycelium \\
Cell morphology & Spore-bearing hyphae & Spore-bearing hyphae \\
Gram reaction & + & + \\
Oxidase activity & + & + \\
Halo size* $(\mathbf{m m})$ & 11 & 10 \\
\hline
\end{tabular}

*net diameter measured from the edge of the colony to the outer edge of the halo, after 4 days of growth.

share positive gram reaction and presence of oxidase activities (Table 2).

\section{Screening of cellulolytic microorganisms in liquid medium}

A further screening of the four selected microorganisms was performed by cultivating them in liquid medium and assaying culture supernatants for cellulase production by both plate method on CMC and AZO-CMCase activity assay. The qualitative plate medium assay showed that cellulase production by the actinomycete strain G12 starts from the 1st day with a maximum at the 6th day. AZO-CMCase activity assay confirmed G12 to be the most productive strain, with a production $\sim 4$ fold higher than the other tested strain, as shown in Figure 1.

\section{Molecular identification}

The strain G12 was identified by sequencing of $16 \mathrm{~S}$ rRNA gene and it was shown to belong to Streptomyces sp.

\section{Optimization of cellulolytic activity production by the selected Streptomyces G12 strain}

The effect of carbon source on cellulase production by Streptomyces G12 strain was tested, using different concentrations $(0.1 \%, 0.5 \%$, and $1 \%)$ of CMC, substituting CMC with glucose, cellobiose, xylose or xylan, and also testing combinations of CMC and glucose or cellobiose. $1 \% \mathrm{CMC}$ was proved to be the best condition for cellulase activity production, reaching a value of $0.0875 \pm$
$0.025 \mathrm{UmL}^{-1}$ (at the 3rd day), that was 1.75-, 2.5-, 3-, 5and 7 -fold higher than that reached in the presence of 0.5\% CMC, xylan, cellobiose, xylose and 0.1\% CMC, respectively.

Then, the order of cellulase activity production was $1 \%$ $\mathrm{CMC}>0.5 \% \mathrm{CMC}>$ xylan $>$ cellobiose $>$ xylose $>0.1 \%$ CMC. As far as cellulase activity production by actinomycetes is concerned, very variable effects were reported for other strains. Cellobiose and glucose have been previously reported as good [6,7,28] or poor [16,29-31] inducers but they may also act as repressors of cellulase activity in some cases [6,32,33]. Xylose and xylan are often reported as non inducing cellulase activity $[7,16,30]$, but in some cases they stimulate cellulase production [29,30,34].

The effect of nitrogen source concentration and nature was also investigated, but no positive effect was obtained either replacing yeast extract with $0.3 \mathrm{gL}^{-1}$ urea [33] or increasing yeast extract concentration by 2-fold [15,35]. When influence of temperature was analyzed, similar cellulase activity levels by Streptomyces G12 were achieved (Figure 2A). The highest cellulase production $\left(0.1 \mathrm{UmL}^{-1}\right)$ in liquid medium was achieved at $28^{\circ} \mathrm{C}$, in the presence of $1 \% \mathrm{CMC}$ and $0.05 \%$ yeast extract, after 6 days of incubation (Figure 2A).

Because of the low endoglucanase activity levels obtained by growing Streptomyces sp. strain G12 on the tested soluble substrates, an inducing carbon source was searched among insoluble substrates, often reported as good

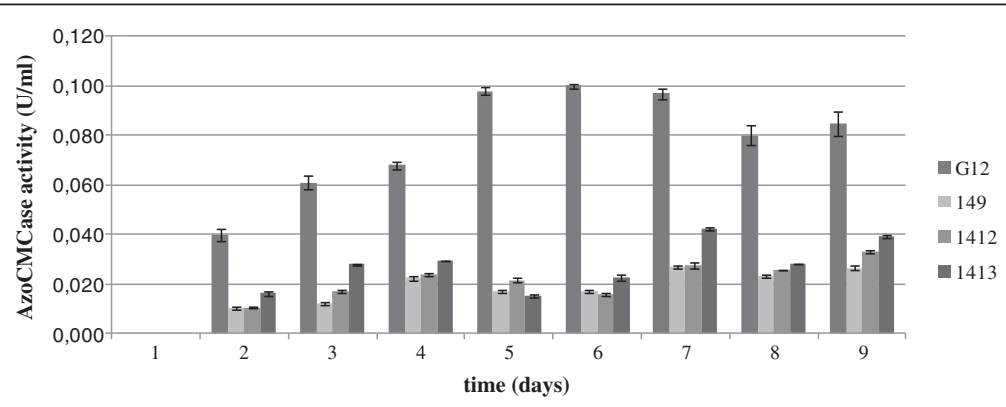

Figure 1 Cellulase activity production of the selected actinomycete strains. The results reported in this figure correspond to mean values of the three independent experiments performed in three replicates. 

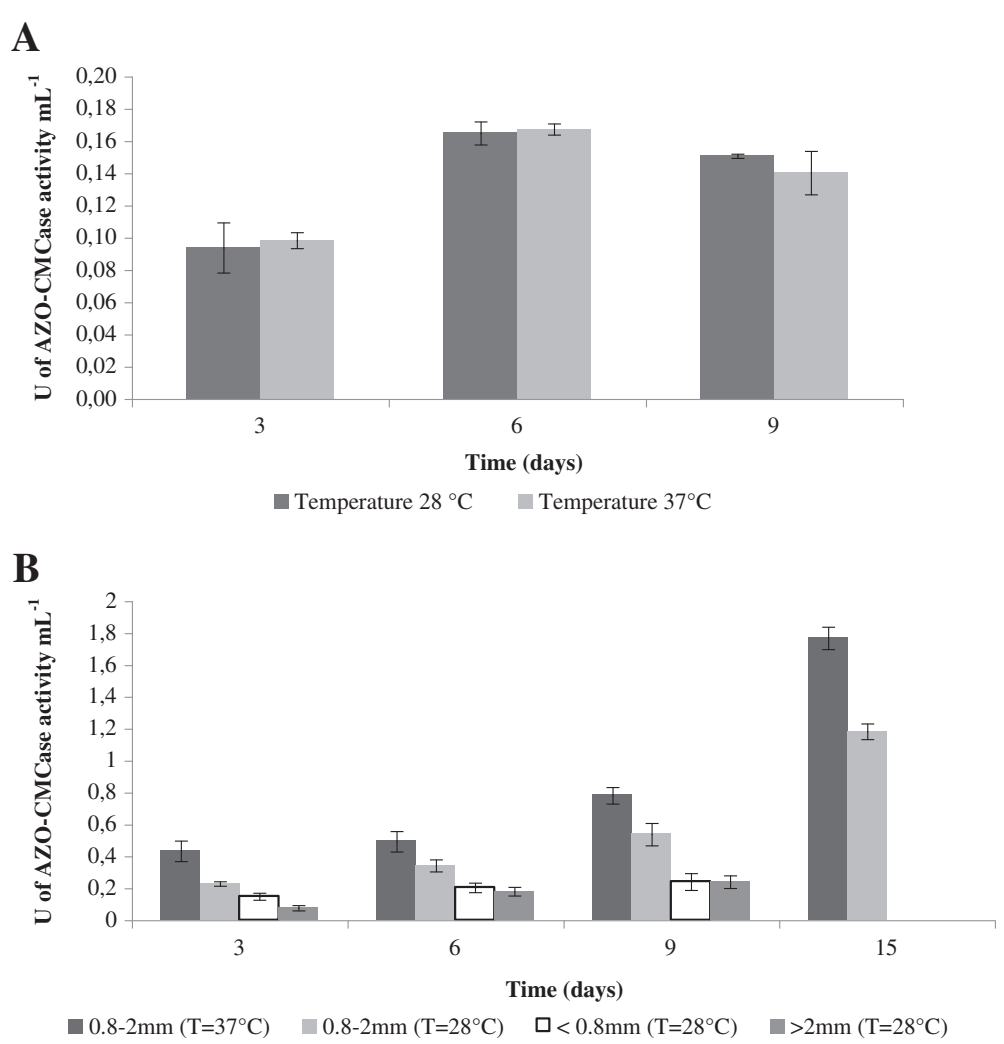

Figure 2 Cellulase activity production levels achieved by Streptomyces G12 in: (A) liquid culture in the presence of $1 \%$ CMC at different temperatures; (B) submerged fermentation on wheat straw with different sizes $(<0.8 \mathrm{~mm} ; 0.8-2 \mathrm{~mm} ;>2 \mathrm{~mm})$ at $28^{\circ} \mathrm{C}$ and on wheat straw (0.8-2 $\mathbf{m m}$ particles) at different temperatures. The results reported in this figure correspond to mean values of the three independent experiments performed in three replicates.

inducers of lignocellulosic activity [7,16,29,36]. Therefore, a submerged fermentation on wheat straw was set up. These fermentation conditions were shown to be the best ones among those explored, thus encouraging application of the isolated strain to waste upgrading by solid state fermentation. Comparing different wheat straw sizes $(<0.8 \mathrm{~mm} ; 0.8$ $2 \mathrm{~mm} ;>2 \mathrm{~mm}$ ), it was shown that particles in the range $0.8-2 \mathrm{~mm}$ give the highest production level (Figure $2 \mathrm{~B}$ ). When yeast extract concentration was increased up to $0.7 \%$ $[15,28]$, no effect on cellulase activity production was revealed. Temperature strongly affects cellulase production in the presence of wheat straw as carbon source, and increasing from 28 to $37^{\circ} \mathrm{C}$ enhances cellulase activity by 1.5 -fold (Figure 2B). Analysis of time course revealed that cellulase production continuously increases up to around $1.80 \mathrm{UmL}^{-1}$ at the 15 th day of the growth.

\section{Cellulases identification}

Proteins putatively responsible for cellulase activity were tentatively identified after a fractionation on a semidenaturing SDS-PAGE where samples from the supernatant of the cell cultures were loaded without any denaturing treatment. The resulting gel was laid over another gel containing CMC as substrates for cellulase activity detection. Two activity positive bands were visualized, and in correspondence to these active bands, slices were excised from the SDS-PAGE and subjected to protein identification after in situ digestion and LCMS/MS analysis of the peptide mixtures. Raw data were used to search non redundant NCBI database available on the net with no taxonomic restriction with the MS/ MS ion search program on a MASCOT server as described above.

Several proteins could be confidently identified in different Streptomyces spp., two of which belong to the class of Carbohydrate active enzymes: 4 peptides matched to peptides present in the sequence of a GH6 family endoglucanase from Streptomyces halstedii (P33682), accounting for $19 \%$ of its protein sequence, and 8 peptides matched to peptides that are in the sequence of a GH12 family cellulase from Streptomyces xylophagus (D2D3J0), accounting for $41 \%$ of its protein sequence (Table 3 ).

\section{Sequences of the cellulase gene and its derived protein} The gene coding for the cellulase from Streptomyces G12 strain similar to GH12 family cellulase from 
Table 3 Results of protein identification in the SDS-PAGE in correspondence to the active bands including as significative only proteins identified with at least two peptides

\begin{tabular}{|c|c|c|c|}
\hline $\begin{array}{l}\text { Identified protein } \\
\text { (Accession number) }\end{array}$ & Total score $^{a}$ & $\begin{array}{l}\text { Matched sequence } \\
\text { (individual ion score) }\end{array}$ & $\begin{array}{l}\text { Sequence } \\
\text { coverage (\%) }\end{array}$ \\
\hline \multirow[t]{4}{*}{ Endoglucanase I (gi|544459) } & 342 & LPILVAYNIYNR (44) & $19 \%$ \\
\hline & & AAAINASIANTPMAR (66) & \\
\hline & & YGYTKPFWDTSR (50) & \\
\hline & & QAPNTWVYMDAGNPR (92) & \\
\hline \multirow[t]{8}{*}{ beta-1,4-endoglucanase (gi|224555766) } & 418 & TEIMIWFNR (25) & $41 \%$ \\
\hline & & VGPIQPIGSQVGTADVAGR (91) & \\
\hline & & WGTSATQCVTATDSGFR (27) & \\
\hline & & TDGVNRTEIMIWFNR (43) & \\
\hline & & SYPSVFNGCHYTNCSPGTALPAR (33) & \\
\hline & & WGTSATQCVTATDSGFRVTQADGSVPTDGAPK (37) & \\
\hline & & LGFTLPSGQSWHAWNASVAPSSGAVTATGPADSPR (49) & \\
\hline & & INGISSAPSSISYGYVDNAVYNASYDIWLDPTPR (49) & \\
\hline
\end{tabular}

${ }^{a}$ lons score is $-10^{*} \log (\mathrm{P})$, where $\mathrm{P}$ is the probability that the observed match is a random event. Individual ions scores $>48$ indicate identity or extensive homology $(\mathrm{p}<0.05)$. Protein scores are derived from ions scores as a non-probabilistic basis for ranking protein hits. (http://www.matrixscience.com/help/ interpretation_help.html).

Streptomyces xylophagus (D2D3J0) was synthesized by PCR on Streptomyces G12's genomic DNA using as primers both degenerate oligonucleotides whose sequences were designed on the basis of sequences of peptides identified by proteomics or sequences of peptides in similar proteins and specific oligonucleotides whose sequences were designed on the basis of sequence of amplified central region (Table 1), to amplify three overlapped fragments.

A signal peptide sequence of 37 amino acids was singled out by SignalP 4.0 Server (http://www.cbs.dtu. $\mathrm{dk} /$ services/SignalP/). The mature protein is 342 amino acids in length and has a calculated molecular mass of 35369.67 Da.

Three potential N-glycosylation sites (Asn-X-Ser/Thr) were found in deduced amino acid sequence namely Asn154, Asn192 and Asn 293.

Similarity searches performed with Basic Local Alignment Search Tool (BLAST http://www.ebi.ac.uk/Tools/ sss/wublast/) using the deduced amino acid sequence of CelStrep as the query revealed its belonging to family GH12 enzymes (http://www.cazy.org/GH12.html; [37]) extracted from the Carbohydrate-active enzymes database (http://www.cazy.org/, [38]). The best hits (99\% and 93\% identities) were with Beta-1,4-endoglucanase from Streptomyces xylophagus (EMBL Accession FJ441063) and eglS Cellulase from Streptomyces rochei [39] (EMBL Accession X73953), respectively, followed by enzymes from Streptomyces ghanaensis ATCC 14672 (EMBL Accession DS999641) and Streptomyces griseoflavus Tu4000 (EMBL Accession GG657758) displaying 84 and $83 \%$ identities respectively.
The family GH12 glycoside hydrolases have a catalytic mechanism with retention of configuration with two glutamates involved in catalysis, one acting as an acid/base and the other as a nucleophile [37].

Three-dimensional structures of family GH12 cellulases have been obtained for one enzyme from Archea Pyrococcus furiosus DSM 3638 (GenBank Accession AAD54602.1), five bacterial enzymes namely from Bacillus licheniformis ATCC 14580/DSM13 [40], from Rhodothermus marinus [41], from Streptomyces lividans 1326 [42], from Streptomyces sp. 11AG8 [43], from Thermotoga maritima MSB8 [44], and six fungal enzymes, namely from Aspergillus aculeatus F-50, Aspergillus aculeatus ATCC 16872 [45], Aspergillus niger CBS 120.49/N400 [46], Humicola grisea ATCC 22081 [47] Hypocrea jecorina QM9414 [48], Hypocrea schweinitzii ATCC 66965 [49]. The catalytic domain is a $\beta$-jelly roll catalytic domain.

Based on the sequence alignment, the potential catalytic glutamates of CelStrep are located at positions 156 (nucleophile) and 240 (acid/base).

\section{Recombinant expression system}

Because of the difficulties to purify the native CelStrep enzyme from Streptomyces G12 due to the presence of another cellulase isoform with very similar chromatographic behavior (data not shown), recombinant expression system was set up to characterize the new cellulase. The enzyme CelStrep was expressed in E. coli. Synthesis of celstrep gene was performed by MrGene (http://mrgene.com). The fulllength celstrep gene sequence including sequence coding for signal peptide was optimized for recombinant expression by adapting it to the E. coli codon usage. 
The celstrep gene was expressed under the control of T7 RNA polymerase promoter in E. coli strain BL21 CodonPlus (DE3) RP. Protein expression was induced with $1 \mathrm{mM}$ IPTG added to the cells grown until 1 $\mathrm{OD}_{600}$, for 6 hours at $37^{\circ} \mathrm{C}$. $1 \mathrm{Uml}^{-1}$ of Azo-CMCase activity was detected in the culture supernatant, and a similar activity level was revealed in the soluble fraction of intracellular proteins.

This achievement suggests the applicability of the developed E. coli system as a cell factory for extracellular production of other bacterial cellulases for their purification and characterization, also considering that not native cellulases are present in the bacterial host differently from the fungal host Trichoderma reesei that, on the contrary, is more appropriate for cellulase overproduction due to the very higher level of recombinant expression [50].

\section{Characterization of the recombinant enzyme CelStrep}

The recombinant enzyme CelStrep was purified from culture supernatant of transformed E. coli strain BL21 to apparent homogeneity (Figure 3 ) and subjected to structural and functional characterization. The few manuscripts so far reported on characterization of cellulases from Streptomyces spp. mostly concern native enzymes $[51,52]$. Only one Streptomyces cellulase was so far produced by recombinant expression in E. coli [53].

The estimated molecular weight deduced from SDSPAGE was shown to be around $37,000 \mathrm{Da}$, similar to that deduced from gene sequence of the mature protein. These results are close to those of Wittmann et al. [52], Irdani et al. [53] and Theberge et al. [51] reporting

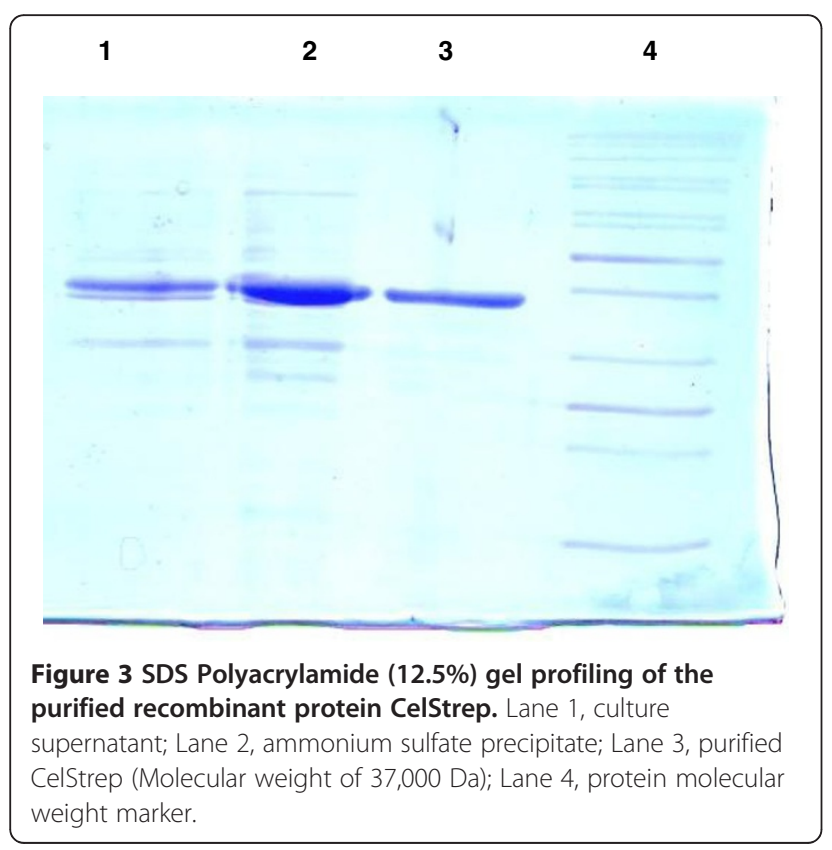

CMCases with a molecular weight of 36, 29 and $46 \mathrm{kDa}$, respectively.

The observed extracellular production of the mature active protein suggests that celstrep leader sequence could allow extracellular production of other recombinant proteins showing the potential of the developed $E$. coli system for extracellular production of bacterial cellulases and, possibly, other enzymes, for their characterization.

An optimum temperatures of $50^{\circ} \mathrm{C}$ was identified for CelStrep (Figure 4), like that reported by Theberge et al. [51] for the endoglucanase from Streptomyces lividans 66 and lower than the optimum temperature $\left(65^{\circ} \mathrm{C}\right)$ reported by Irdani et al. [53] for the purified endoglucanase from Streptomyces rochei.

The recombinant enzyme CelStrep showed a higher thermoresistance (Figure 5) than that of S. rochei cellulase [53], exhibiting a half life of around $24 \mathrm{~h}$ and $96 \mathrm{~h}$ at $60^{\circ} \mathrm{C}$ and $50^{\circ} \mathrm{C}$, respectively and showing a retention of around $80 \%$ of activity after $96 \mathrm{~h}$ at $40^{\circ} \mathrm{C}$.

CelStrep follows a Michaelis-Menten kinetics towards CMC: the $K_{M}$ for this substrate is $9.7 \pm 0.8 \mathrm{mg} \mathrm{ml}^{-1}$ similar to that reported by Theberge et al. [51], and 9-fold lower than that reported by Wittmann et al. [52], and the $\mathrm{v}_{\max }$ is $3469 \pm 35 \mu \mathrm{M} \mathrm{min}^{-1}$ corresponding to $600 \mathrm{IU} / \mathrm{mg}$ of enzyme, that is 6- and 30- fold higher than those reported by Wittmann et al. [52] and Theberge et al. [51], respectively.

\section{Conclusions}

In this manuscript, different microorganisms isolated from compost were screened for their cellulolytic activity and the bacterium producing the highest cellulolytic activity levels was identified by $16 \mathrm{~S}$ rRNA sequencing and designated as Streptomyces sp. strain G12. This strain was shown to produce the highest cellulolytic activity levels even in comparison to Bacillus cellulolytic strains isolated in similar conditions [54]. In order to develop a recombinant expression system for cellulases from

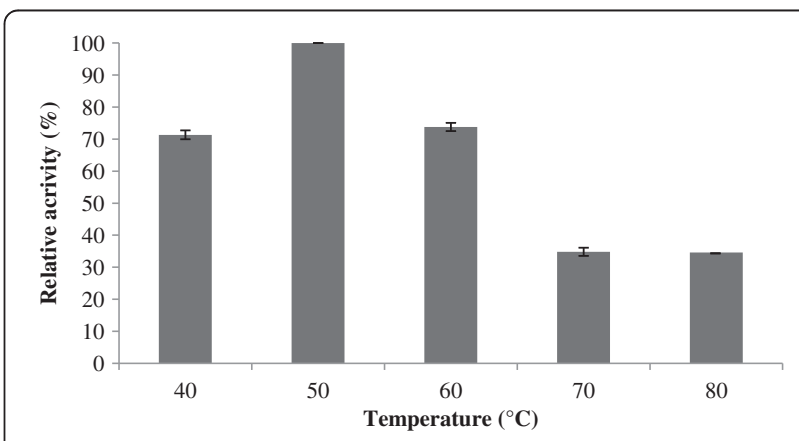

Figure 4 Effect of temperature on the Azo-CMCase enzyme activity of the purified recombinant protein CelStrep. The Azo-CMCase activity was measured at the temperatures ranging from $40^{\circ} \mathrm{C}$ to $80^{\circ} \mathrm{C}$. 

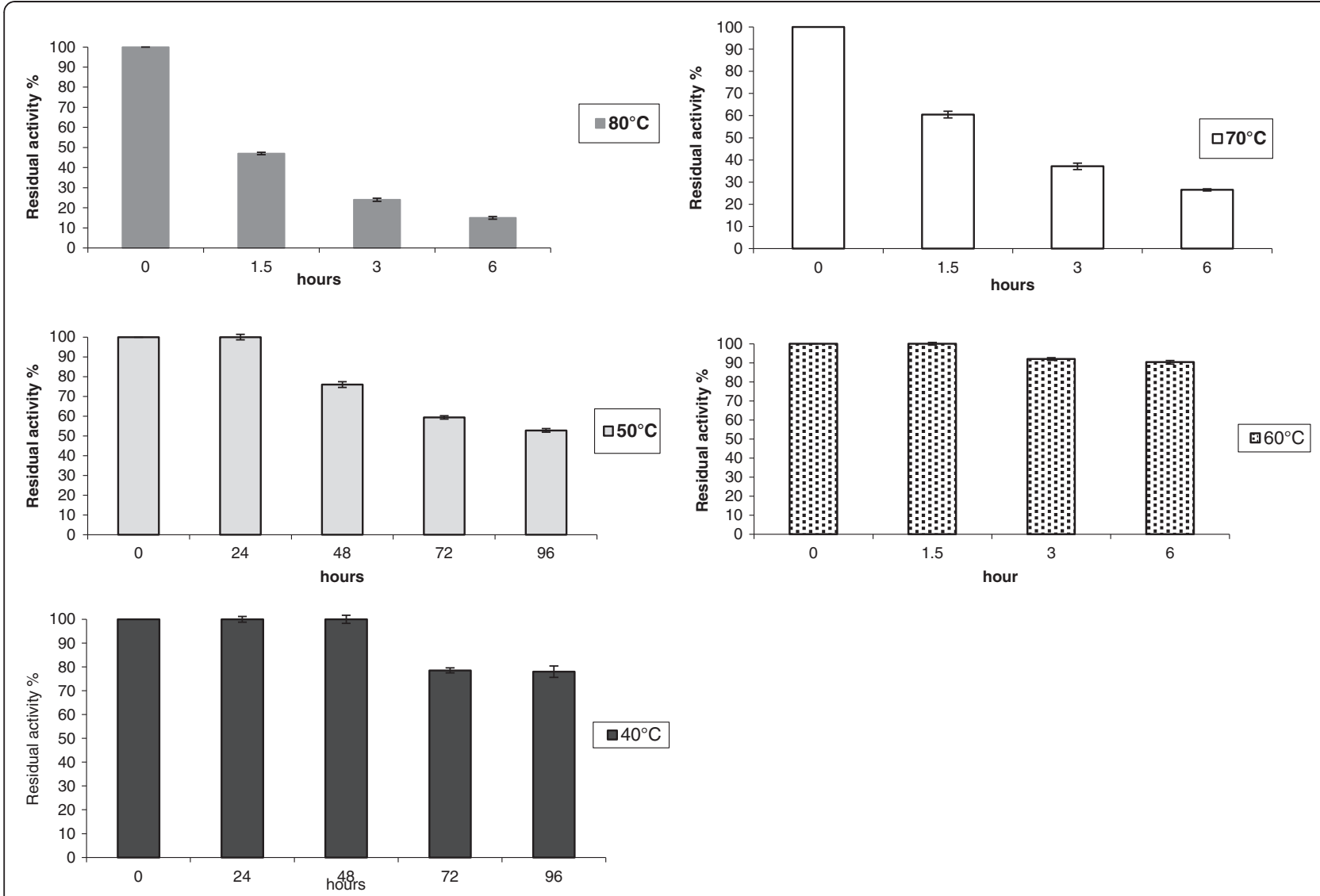

Figure 5 Thermo-resistance of the purified recombinant protein CelStrep. Thermo-resistance was determined after incubating the enzyme at different temperatures ranging from $40^{\circ} \mathrm{C}$ to $80^{\circ} \mathrm{C}$, at pH 6.2 for different intervals of time, and the residual enzyme activities were determined by the Azo-CMCase assay. The results reported in this figure correspond to mean values of the three independent experiments performed in three replicates.

Streptomyces sp. G12, allowing their purification and characterization, the gene coding for one of the enzymes identified by proteomics as responsible for its cellulase activity was amplified and sequenced, and named celstrep. Analysis of the amino acid sequence of CelStrep, placed the enzyme in family 12 of the glycoside hydrolases. A heterologous expression system was set up in $E$. coli using the leader sequence of CelStrep. The active recombinant enzyme was purified from culture supernatant and characterized standing out for its thermoresistance. Besides increasing its potential of CelStrep for cellulose conversion, its thermoresistance would make this cellulase an appropriate candidate as a scaffold for directed evolution experiments aimed at developing better biocatalysts for cellulosic biofuel production, coherently with the original theory [55] that supports the direct relationship between thermostability, mutational robustness and evolutionary capacity.

Moreover, it is worth noting that the observed extracellular production of the mature active recombinant CelStrep protein in E. coli suggests that celstrep leader sequence could allow extracellular production of other recombinant proteins. This shows the potential of the developed $E$. coli system as a cell factory for extracellular production not only of bacterial cellulases but also of other bacterial enzymes for their characterization, highlighting general interest of these findings.

\section{Competing interests}

The authors declare that they have no competing interests.

\section{Authors' contributions}

AA carried out analysis of time course of cellulase activity in liquid cultures of the selected microorganisms, optimization of cellulase production in liquid culture by the strain G12, cloning and recombinant expression of celstrep. OP contributed to conceiving the study and participated in its design and coordination for the part of isolation of microorganisms, screening of cellulolytic microorganisms on solid medium, characterization of selected microorganisms and identification of the strain G12 and helped to draft the manuscript. W carried out screening of the cellulolytic bacteria on solid media, phenotypic and molecular characterization of the selected strains, and identification of the strain G12. LB carried out the interpretation of the proteomic analyses and helped to draft the manuscript. CG carried out the proteomic analyses. VF contributed to conceiving the study and participated in its design and coordination for the part of screening of selected microorganisms in liquid cultures, optimization of cellulase production by the strain $\mathrm{G} 12$, cloning and recombinant expression of celstrep 
and purification and characterization of recombinant CelStrep protein and drafted the manuscript. All authors read and approved the final manuscript.

\section{Acknowledgements}

This work was supported by grant from the Ministero dell'Università e della Ricerca Scientifica -Industrial Research Project "Integrated agro-industrial chains with high energy efficiency for the development of eco-compatible processes of energy and biochemicals production from renewable sources and for the land valorization (EnerbioChem)" PON01_01966, funded in the frame of Operative National Programme Research and Competitiveness 2007-2013 D. D. Prot. n. 01/Ric. 18.1.2010.

\section{Author details}

'Department of Chemical Sciences, University of Naples "Federico II", Complesso Universitario Monte S. Angelo, via Cintia, 4, 80126, Naples, Italy. ${ }^{2}$ Department of Food Science, University of Naples "Federico II", Via Università 100, 80055, Portici, Napoli, Italy. ${ }^{3}$ School of Biotechnological Sciences, University of Naples "Federico II", Portici, Napoli, Italy.

Received: 20 October 2012 Accepted: 16 December 2012 Published: 26 December 2012

\section{References}

1. Faraco V, Hadar Y: The potential of lignocellulosic ethanol production in the Mediterranean basin. Renew Sust Energ Rev 2011, 15:252-266.

2. Lynd LR, Larson E, Greene N, Laser M, Sheehan J, Dale BE, McLaughlin S, Wang M: The role of biomass in America's energy future: framing the analysis. Biofuels Bioprod Bioref 2009, 3:113-123.

3. Lynd LR, Laser MS, Bransby D, Dale BE, Davison B, Hamilton R, Himmel M, Keller M, McMillan JD, Sheehan J, Wyman CE: How biotech can transform biofuels. Nat Biotechnol 2008, 26(2):169-172

4. Gusakov AV, Salanovich TN, Antonov Al, Ustinov BB, Okunev ON, Burlingame R, Emalfarb M, Baez M, Sinitsyn AP: Design of highly efficient cellulase mixtures for enzymatic hydrolysis of cellulose. Biotechnol Bioeng 2007, 97(5):1028-1038.

5. Crawford DL, McCoy E: Cellulases of Thermomonospora fusca and Streptomyces Thermodiastaticus. Appl Environ Microbiol 1972, 24:150-152.

6. Lin E, Wilson DB: Regulation of 3-1,4-endoglucanase synthesis in Thermomonospora fusca. Appl Environ Microb 1987, 53(6):1352-1357.

7. Spiridonov NA, Wilson DB: Regulation of biosynthesis of individual cellulases in Thermomonospora fusca. J Bact 1998, 180(14):3529-3532.

8. Deng Y, Fong SS: Influence of culture aeration on the cellulase activity of Thermobifida fusca. Appl Microbiol Biotechnol 2010, 85:965-974.

9. Stutzenberger FJ: Cellulase production by Thermomonospora curvata isolated from municipal solid waste compost. App Microb 1971, 22(2):147-152

10. Stutzenberger FJ: Cellulolytic activity of Thermomonospora curvata: nutritional requirements for cellulase production. Appl Microb 1972, 24(1):77-82.

11. Stutzenberger FJ: Cellulolytic activity of Thermomonospora curvata: optimal assay conditions, partial purification, and product of the cellulase. Appl Microbiol 1972, 24(1):83-90

12. Fennington $G$, Neubauer D, Stutzenberger F: Cellulase biosynthesis in a catabolite repression-resistant mutant of Thermomonospora curvata. Appl Environ Microb 1984, 47(1):201-204.

13. Lin S-B, Stutzenberger FJ: Purification and characterization of the major -1,4-endondoglucanase from Thermomonospora curvata. J Appl Bact 1995, 79:447-453.

14. Antai SP, Crawford DL: Degradation of softwood, hardwood, and grass lignocelluloses by Two Streptomyces strains. Appl Env Microb 1981, 42(2):378-380.

15. Semêdo LT, Gomes RC, Bon EPS, Soares RMA, Linhares LF, Coelho RR: Endocellulase and exocellulase activities of Two Streptomyces strains isolated from a forest soil. Appl Biochem Biotech 2000, 84-86:267-276.

16. Godden B, Legon T, Helvenstein P, Penninckx M: Regulation of the production of hemicellulolytic and cellulolytic enzymes by a Streptomyces sp. Growing on lignocellulose. J Gen Microb 1989, 135:285-292.

17. George SP, Ahmad A, Rao MB: A novel thermostable xylanase from Thermomonospora sp.: influence of additives on thermostability. Bioresour Technol 2001, 78:221-224.
18. Hankin L, Anagnostic SL: Solid media containing carboxymethylcellulose to detect CX cellulose activity of micro-organisms. J Gen Microbiol 1977, 98:109-115.

19. Moore RL, Basset BB, Swift MJ: Developments in the Remazol Brilliant Blue dye-assay for studying the ecology of cellulose decomposition. Soil Biol Biochem 1979, 11:311-312.

20. Kluepfel D: Screening of procaryotes for cellulose-and hemicellulose degrading enzymes. Methods Enzymol 1988, 160:180-186.

21. Halebian S, Harris B, Finegold S, Rolfei R: Rapid method that aids in distinguishing gram-positive from gram-negative anaerobic bacteria. J Clin Microbiol 1981, 13:444-448.

22. Kumar $V$, Bharti A, Gusain O, Bisht GS: An improved method for isolation of genomic DNA from filamentous actinomycetes. J Sci Eng Tech Mgt 2010, 2:10-13.

23. Blaiotta G, Pepe O, Mauriello G, Villani F, Andolfi R, Moschetti G: 16S-23S rDNA intergenic spacer region polymorphism of Lactococcus garvieae Lactococcus raffinolactis and Lactococcus lactis as revealed by PCR and nucleotide sequence analysis. Syst Appl Microbiol 2002, 25:520-527.

24. Laemmli UK: Cleavage of structural proteins during the assembly of the head of bacteriophage T4. Nature 1970, 227:680-685.

25. Beguin P: Detection of cellulase activity in polyacrylamide gels using Congo red-stained agar replicas. Anal Biochem 1983, 131:333-336.

26. Raeder $V$, Broda P: Preparation and characterization of DNA from lignin degrading fungi. Methods Enzymol 1988, 161B:211-220.

27. Miller GL: Use of dinitrosalicylic acid reagent for the determination of reducing sugar. Anal Chem 1959, 31:426-428.

28. Chellapandi P, Jani HM: Production of endoglucanase by the native strains of Streptomyces isolates in submerged fermentation. Braz J Microbiol 2008, 39:122-127.

29. Okeke BC, Paterson A: Simultaneous production and induction of Cellulolytic and Xylanolytic Enzymes in a Streptomyces sp. World J Microb Biot 1992, 8:483-487.

30. Tuncer M, Ball AS, Rob A, Wilson MT: Optimization of Extracellular Lignocellulolytic Enzyme Production by a thermophilic Actinomycete Thermomonospora Fusca BD25. Enzyme Microb Tech 1999, 25:38-47.

31. Jang H-D, Chen K-S: Production and characterization of thermostable cellulases from Streptomyces transformant T3-1. World J Microb Biot 2003 19:263-268

32. Wood WE, Neubauer DG, Stutzenberger FJ: Cyclic AMP levels during induction and repression of cellulase biosynthesis in thermomonospora curvata. J Bacteriol 1984, 160:1047-1054.

33. Alani F, Anderson WA, Moo-Young M: New isolate of Streptomyces Sp. With novel thermoalkalotolerant cellulases. Biotechnol Lett 2008, 30:123-126.

34. Mackenzie CR, Bilous D, Schneider H, Johnston KG: Induction of Cellulolytic and Xylanolytic Enzyme Systems in Streptomyces spp. Appl Environ Microbiol 1987, 53:2835-2839.

35. Nurkanto A: Cellulolitic activities of actinomycetes isolated from soil rhizosphere of waigeo, raja ampat. West papua. J Tanah Trop 2009, 14:239-242.

36. Ball AS, McCarthy AJ: Saccharification of Straw by Actinomycete Enzymes. J Gen Microbiol 1988, 134:2139-2147.

37. Henrissat B, Bairoch A: Updating the sequence-based classification of glycosyl hydrolases. J Biochem 1996, 316:695-696. Printed in Great Britain

38. Cantarel BL, Coutinho PM, Rancurel C, Bernard T, Lombard V, Henrissat B: The carbohydrate-active enzymes database (CAZy): an expert resource for glycogenomics. Nucleic Acids Res 2009, 37:233-238.

39. Perito B, Hanhart E, Irdani T, Iqbal M, McCarthy AJ, Mastromei G: Characterization and sequence analysis of a Streptomyces rochei A2 endoglucanase-encoding gene. Gene 1994, 148:119-124.

40. Gloster TM, Ibatullin FM, Macauley K, Eklof JM, Roberts S, Turkenburg JP, Bjornvad ME, Danielsen PLJ, Johansen KS, Borchert TV, Wilson KS, Brumer $H$, Davies GJ: Characterization and three-dimensional structures of two distinct bacterial xyloglucanases from families GH5 and GH12. J Biol Chem 2007, 282:19177-19189.

41. Crennell SJ, Hreggvidsson GO, Nordberg Karlsson E: The structure of Rhodothermus marinus Cel12A, a highly thermostable family 12 endoglucanase, at 1.8 A resolution. J Mol Biol 2002, 320(4):883-897.

42. Sulzenbacher G, Shareck F, Morosoli R, Dupont C, Davies GJ: The Streptomyces lividans family 12 endoglucanase: construction of the 
catalytic cre, expression, and X-ray structure at $1.75 \mathrm{~A}$ resolution. J Biochem 1997, 36:16032-16039.

43. Sandgren M, Gualfetti PJ, Shaw A, Gross LS, Saldajeno M, Day AG, Jones TA, Mitchinson C: Comparison of family 12 glycoside hydrolases and recruited substitutions important for thermal stability. J Prot Sci 2003, 12(4):848-860

44. Cheng Y-S, Ko T-P, Wu T-H, Ma Y, Huang C-H, Lai H-L, Wang AH-J, Liu J-R, Guo R-T: Crystal structure and substrate-binding mode of cellulase 12A from Thermotoga maritima. Proteins 2011, 79(4):1193-1204.

45. Yoshizawa T, Shimizu T, Hirano H, Sato M, Hashimoto H: Structural basis for the inhibition of xyloglucan-specific endo-beta-1,4-glucanase (XEG) by XEG-protein inhibitor. J Biol Chem 2012, 287(22):18710-18716.

46. Khademi S, Zhang D, Swanson SM, Wartenberg A, Witte K, Meyer EF: Determination of the structure of an endoglucanase from Aspergillus niger and its mode of inhibition by palladium chloride. Acta Crystallogr D: Biol Crystallogr 2002, 58(4):660-667.

47. Sandgren M, Gualfetti PJ, Paech C, Paech S, Shaw A, Gross LS, Saldajeno M, Berglund Gl, Jones TA, Mitchinson C: The humicola grisea Cel12A enzyme structure at 1.2 A resolution and the impact of its free cysteine residues on thermal stability. Protein Sci 2003, 12(12):2782-2793.

48. Sandgren M, Shaw A, Ropp TH, Wu S, Bott R, Cameron AD, Stahlberg J, Mitchinson C, Jones TA: The X-ray crystal structure of the Trichoderma reesei family 12 endoglucanase 3 , Cel12A, at 1.9 A resolution. J Mol Biol 2001, 308(2):295-310.

49. Sandgren M, Gualfetti PJ, Shaw A, Gross LS, Saldajeno M, Day AG, Jones TA, Mitchinson C: Comparison of family 12 glycoside hydrolases and recruited substitutions important for thermal stability. Protein Sci 2003, 12(4):848-860.

50. Zou G, Shi S, Jiang Y, van den Brink J, de Vries RP, Chen L, Zhang J, Ma L, Wang C, Zhou Z: Construction of a cellulase hyper-expression system in Trichoderma reesei by promoter and enzyme engineering. Microb Cell Fact 2012, 11:21-32

51. Theberge M, Lacaze P, Shareck F, Morosoli R, Kluepfel D: Purification and characterization of an endoglucanase from Streptomyces lividans 66 and DNA sequence of the gene. Appl Environ Microb 1992, 58:815-820.

52. Wittmann S, Shareck F, Kluepfel D, Morosoli R: Purification and characterization of the CelB endoglucanase from Streptomyces lividans 66 and DNA sequence of the encoding gene. Appl Environ Microb 1994, 60:1701-1703.

53. Irdani T, Perito B, Mastromei G: Characterization of a streptomyces rochei endoglucanase. Ann N Y Acad Sci 1996, 782:173-181.

54. Ventorino V, Amore A, Faraco V, Blaiotta G, Pepe O: Selection of cellulolytic bacteria for processing of cellulosic biomass. J Biotechnol 2010, 150:S181-S181.

55. Bloom JD, Labthavikul ST, Otey CR, Arnold FH: Protein stability promotes evolvability. Proc Natl Acad Sci USA 2006, 103:5869-5874.

doi:10.1186/1475-2859-11-164

Cite this article as: Amore et al:: Cloning and recombinant expression of a cellulase from the cellulolytic strain Streptomyces sp. G12 isolated from compost. Microbial Cell Factories 2012 11:164.

\section{Submit your next manuscript to BioMed Central and take full advantage of:}

- Convenient online submission

- Thorough peer review

- No space constraints or color figure charges

- Immediate publication on acceptance

- Inclusion in PubMed, CAS, Scopus and Google Scholar

- Research which is freely available for redistribution

Submit your manuscript at www.biomedcentral.com/submit
( Biomed Central 